\title{
Study on the Problem that Township Enterprises Are Facing and It's Strategy
}

\author{
Ziqing Wei, Yuan Wang \\ School of Jilin Agricultural University, Changchun 13000, China
}

Keywords: Township Enterprises, Development.

\begin{abstract}
Township enterprises is the outcome that Chinese farmers strive for wealthy lives and development. They made great contribution to socialist construction and national economy. When the society changes and progress, they meet obstacles. Such issues are placed at township enterprises: economic benefits is low; industrial structure is unreasonable; the shortages of talents; the property right is unclear, etc. Therefore township enterprises do as the focus on solving the problems of 'agriculture, rural areas and farmers', people should solve the problems though these means: clear the property right; obsorb the talents; adjust the industrial construction; policy support.
\end{abstract}

\section{The Contents And The Value Of Township Enterprises\}

\subsection{The Contents Of Township Enterprises}

Township enterprises is a concept with Chinese characteristers. They made great contribution to Chinese economic progression and rural development.<<Law of People's Republic Of China On Township Enterprises >> published on January First 1997,setted:Town enterprises is mainly invested by rural collective economic organization or farmers. They are composrd by tertiary industry and industry establishen by individuals or rural collectivity undertaking the duty of supporting agriculture.Since reform and opening,they act well and bear historical missions.Nowadays, 'agriculture,rural areas and farmers'is still the emphasis of The Communist Part Of China and our country on work-field.Certainly, the realistic significance is awfully outstanding.Booming and consolidating township enterprises is a valid method to settle 'agriculture,rural areas and farmers'.

\subsection{The value of township enterprises}

DengXiaoping said:"In the rural reform,the great result that we never expected is the boom of township enterprises. These enterprises contain various kinds of small enterprises practicing marketoriented economy and running diverse industries."The development of township enterprises provided solid material base and technical support of agricultural technique.Because the township enterprises developed at top speed , a large number of superfluous labor diverted from agricultural sectors to other sectors, and the farmers' earning advavced markedly. The rise of township enterprises prolong the industry chain,make subsidiary agricultural products flow into cities, realize the appreciation of subsidiary agricultural products. Some city enterprises have been the township enterprises' providers of raw material and the absorbers of finished products or semi-finished products, while making township enterprises become the link of bonding rural areas and cities. Therefore, break the dual economic structure of city and countryside, adjust the rural industry structure,accelerate the progression of agricultural industrialization,prolong industry chain. The development of township enterprises improve the qualities of farmers.

\section{The problems The Township Enterprises Are Facing}

When the society is changing and the reform is deepening,the situation of township enterprises is decadent.In some places,massive township enterprises go bankrupt.It is said:For the reason that the history duty of township enterprises is terminate, it is unnecessary to keep on blossoming township enterprises.Nonetheless, the problems of agriculture,rural areas and farmers'are not yet settled roundly and effectively,it shows that their duties are continuous.DengXiaoping said:"The development is the hard truth.'Develop is the key to settle he problems of agriculture, rural areas and 
farmers' and plights of township enterprises. Furthermore, township enterprises are also facing the following issues:

Firstly, township enterprises' economic effect is low.Enterprises live in straitened circumstances in the condition that local markets integrate with international markets. The capacity of obsorbing surplus rural labor force is weak, which make agreat number of peasant-workers flowed into big and medium-sized cities. The phenomenon increased the burden of cities.

Secondly, in industrial structure, we should pay attention to develop the tertiary industry in the following country-level areas.Gradually,change the situation that the proportion of secondary industry is large while the proportion of the tertiary industry is quite small.Under the pressure of transfer of region structural power. The roads to leading to propelling the urbanization are enrich the farmers,flourishing the rural areas,decreasing the amount of farmers. The roads are also the fundermental experice to realize the modernization and industrialization and settle the problems of 'agriculture,rural areas and farmers' in international community and in China.

Thirdly, the property right of township enterprises is unclear; the government prop dynamics is not enough; The congnition to the strategic position of township enterprises is not penetrating.

\section{The Countermeasure To Develop The Township Enterprises}

Firstly, in modern unbanisation, township enterprises continue to centre on the stretch of industry chain to make a great effort to develop service. Give play the superiorty from the connection of the problems of ' agriculture, rural areas and farmers' and township enterprises. Energetically develop the service that face rural construction, agricultural production, rural life. The key point is on the agriculture and the stretch of rural industry chain. Endeavor to do the supply of capital goods in agricultural sector and preliminary working, reserve, retaining refreshness, transportation, packing of agricultural products. And manage the service suchas: commerce and trade, transportion, information, journey and catering. The best method to increase farmers' income and obsorb the surplus rural labor to take occupations is prolonging the industry chain.

Secondly, on the basis of local preponderant resource and a series of industrial policy in our country, we should adjust industrial structure. On the basis of diversified market demand, we strive to develop preponderant productions and industry, active diversified industries, uplift primary industry, adjust and optimize secondary industry, quicken to develop tertiary industry, vigorously set up intensive agricultural enterprises. We should Vigorously propel to develop township enterprises intensively, which make rural and cities be supported and supplemented with each other. Thus, it is bebeficial to exchange essential production factors. We should reasonably utilize lands, make the best use of limited lands to carry infrastructure through, strength build-up effect, coordinate secondary industry and tertiary industry to develop concertedly.

Thirdly, draw talents into township enterprises and make full use of them reasonably. Enterprises bebefits from the building of a strong contingent of talents. One of the bottlenecks restricking township enterprises is short of talents. Thus, we enhance talents' treatment and recruit the new type talents to bring the new energy to the enterprises. Everybody was let to display his talents fully. And give talents proper positions and room to progress. Therefore, by the ways above talents could fall and rise with enterprises as one unit.

Fouthly, the government posivitly guide and premote the reform of township enterprises. And perfect operation mechanism. The government should supervise the township enterprises ensuring the economic value of collective assets. The government help township enterprises explore management type and organizational form that suit themselves and let them break the limit of ownership, enterprises and communities and approach the preponderant enterprises, industry and products by investment, share, merge, purchase and participation. Township enterprises quicken the pace of technical transformation, enlarge the scale of management, perfect the management, lessen unreasonable administrative intervene, complete operating mechanism, and enhance market competitive power.

The prosperity of the township enterprises is the key point to solve the problems of agriculture, rural areas and farmers'. The farmers depend on their own intelligence and hard work to set up and 
develop the township enterprises. They got outstanding performance. So, the historic mission of the township enterprise is not yet terminate. Facing the new challenges, the governments , the farmers and the enterprises pull together to solve the problems of ' agriculture, rural areas and farmers' comprehensively and furnish solid foundation to resolve the poverty.

\section{References}

[1].Gao cui jie.A Little Talk About The Influence On Rural Economy From The Progress Of The Township Enterprises[J].Statistics And Consulation,2011,(04).

[2],[4].Wu shu xian.Develop Township Enterprises, Quicken The Progress Of Urbanization And Solve The Problems Of'Agriculture, Rural Areas And Farmers'[J].Socialism Studies,2004,(01).

[3].Yang shao pin.Give Full Play To The Important Role From Chinese Township Enterprises Propelling Urbanization[J]. Agricultural Engineering Technology. 